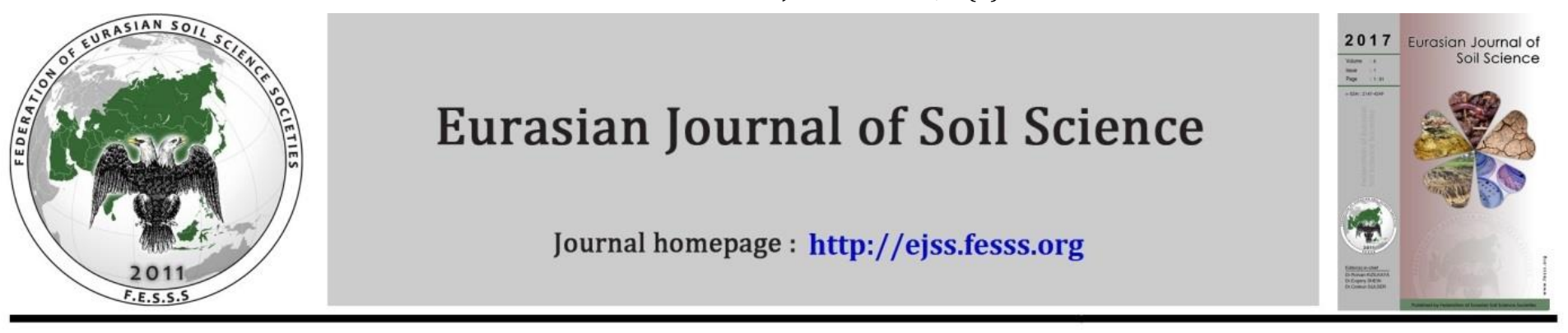

\title{
Distribution, typology and assessment of degraded soils Piedmont Plains Zhetysu Ridge, Kazakhstan
}

\author{
Maira Kussainova *, Konstantin Pachikin, Olga Erokhina
}

Kazakh Research Institute of Soil Science and Agrochemistry named after U.U. Uspanov, Almaty, Kazakhstan

\section{Article Info}

Received : 28.07.2016

Accepted : 19.12 .2016

\begin{abstract}
Identification of land degradation is essential to check the problem and to implement the remedial measures needed. The study area falls under parts of foothill plains Zhetysu Ridge, Kazakhstan, that is an arid region in climate. Recent data on the status of study area refer to the 80s of the last century, and the intensive use of them led to a significant anthropogenic transformation. This study was carried out in 2015-2016 as part of a project aimed to study features and causes of land degradation in foothill plains Zhetysu Ridge, Kazakhstan. Under the conditions of rainfed soil degradation manifests itself in the development of erosion processes, agro depletion of soils, reducing the productivity of agriculture. The use of land for irrigation often accompanied by secondary salinization. In this regard, at present there is need to assess current state of the soil, with the identification of changes in their properties as a result of the impact of various anthropogenic factors and creation of new electronic soil maps and applied the powerful capabilities of advanced remote sensing (RS) and geographic information system (GIS) techniques to identify the geomorphological units and degradation risk assessment. Satellite imagery in addition to the field and laboratory studies to identify salinity-induced soil degradation was adopted in this study. Morphological, chemical and physical characteristics of soils in degraded sites in foothill plains Zhetysu Ridge, Kazakhstan, were depicted. The main results of a thorough evaluation of soil degradation in foothill plains Zhetysu Ridge, Kazakhstan, are presented. The data revealed that extent of salinity-induced degradation was generally related to some physical properties of soil, uncontrolled livestock grazing and previous soil management practices. These results are useful as the basis for designing soil conservation and restoration programs, as a base line for evaluating the performance of conservation programs and for assessing the impact of other soilrelated activities (e.g. agriculture and livestock rising).
\end{abstract}

Keywords: Soil degradation, Kazakhstan, Zhetysu Ridge, geoinformation technologies, types of degradation.

(C) 2017 Federation of Eurasian Soil Science Societies. All rights reserved

\section{Introduction}

The second half of the XX century characterized by a maximum gain of anthropogenic impacts in pedosphere. According to international organizations arable-suitable of the Earth Fund is only about 3-3.5 billion ha, of which nearly 2 billion more or less susceptible to degradation as a result of which the development is lost annually about 7 million ha of arable land (Gabbasova and Habirov, 2010). In the agricultural turnover of Kazakhstan is located 222.5 million ha, of which 33.7 million ha (10.8\%) of arable land, 187.0 million ha of pastures (84.8\%) and grasslands (2.3\%), 1.8 million ha of reserve and perennial

\footnotetext{
${ }^{*}$ Corresponding author.

Kazakh Research Institute of Soil Science and Agrochemistry named after U.U. Uspanov, 050060 Almaty, Kazakhstan

Tel.: + 7 (727) 2694733

E-mail address: madgu@inbox.ru 
plants (2; 0.1\%) (Figure 1) (Medeu and Akiyanova, 2011; Kozybayeva, 2014). The percentage of land Structure as follows: agricultural land $-35.1 \%$, the settlements $-8.8 \%$, land used in industry transport communications defense and other non-agricultural purposes - 1\%, protected areas, recreational, historical and cultural lands $-1.8 \%$, lands of forest fund $-8.9 \%$, lands of water fund- $1.6 \%$, reserve lands $-42.8 \%$ (Figure 2) (Medeu and Akiyanova, 2011).

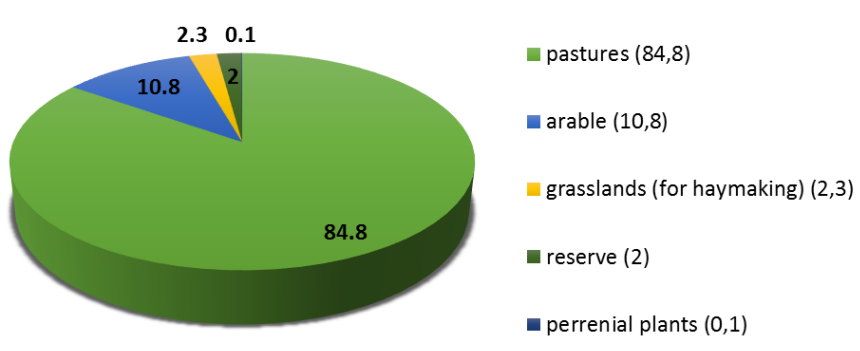

Figure 1. Agricultural lands structure (\%)

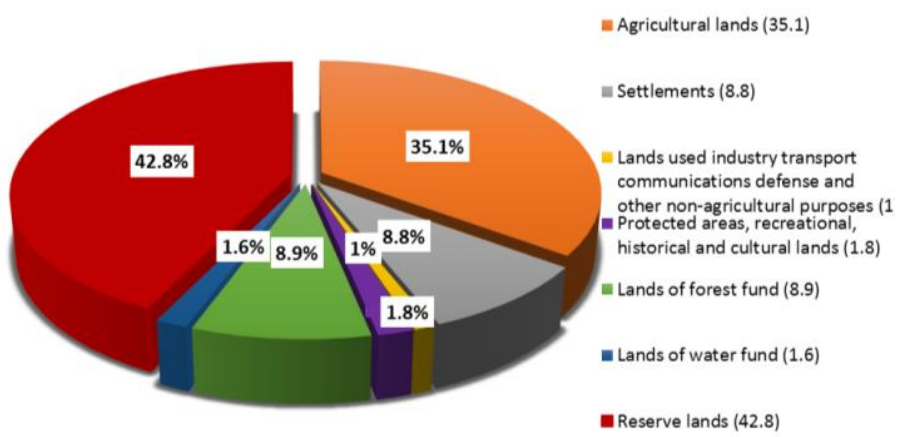

Figure 2. Landuse structure (\%)

Already today about $60 \%$ of the soil cover of Kazakhstan applies in varying degrees to the degraded, depending on the characteristics of natural conditions and the national economic use. Current estimates of degraded and agricultural land distributed as follows: according to the Agency of Land Resources (2011), the area of land subject to water erosion, is 4988.9 thousand ha, and the area of land subject to wind erosion, is 25,493.1 thousand ha, Figures 3, 4 (Medeu and Akiyanova, 2011).

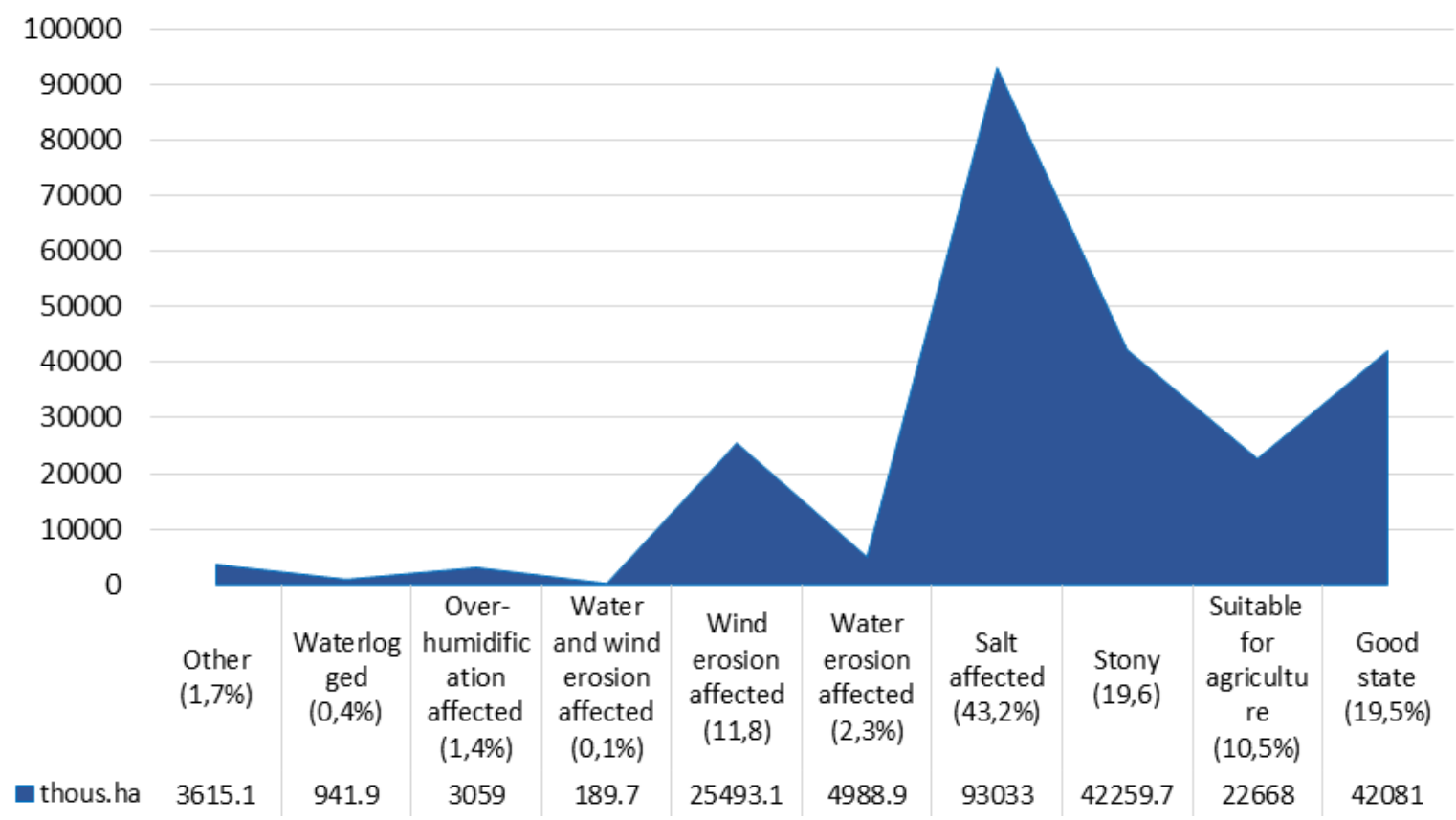

Figure 3. Current state of agricultural lands degradation

For formation of highly adaptive land management, in addition to improving the economic land resources management mechanisms, it is necessary to take measures to improve the quality status of the land based on landscape ecological approach. In this regard special relevance acquired by questions of carrying out soil and geographical researches in the territory of Almaty region for the fair presentation of Kazakhstan's soil resources, conservation and reproduction of soil fertility, control the environmental state of the soil and forecasting trends of its transformation.

These problems can not be solved without a reliable systematic information, including data on the spatial distribution of soil and data about the basic properties of soils (morphological, chemical, physicochemical, physical). Under conditions of transition agricultural to paid land use there is a need to improve the forms and land resource management practices, which is impossible without the development of information support (Dusembekov, 1997). To conduct development related to the solution of practical problems of land 
administration, we must have a reliable and qualitative data on the characteristics of the soils of the region, the structure of soil and its transformation associated with the effect of natural and anthropogenic factors. The main purpose of this study - to give comprehensive qualitative and quantitative assessment of the current state of agricultural land piedmont plains Zhetysu ridge and to develop schemes of rational land use the study area.

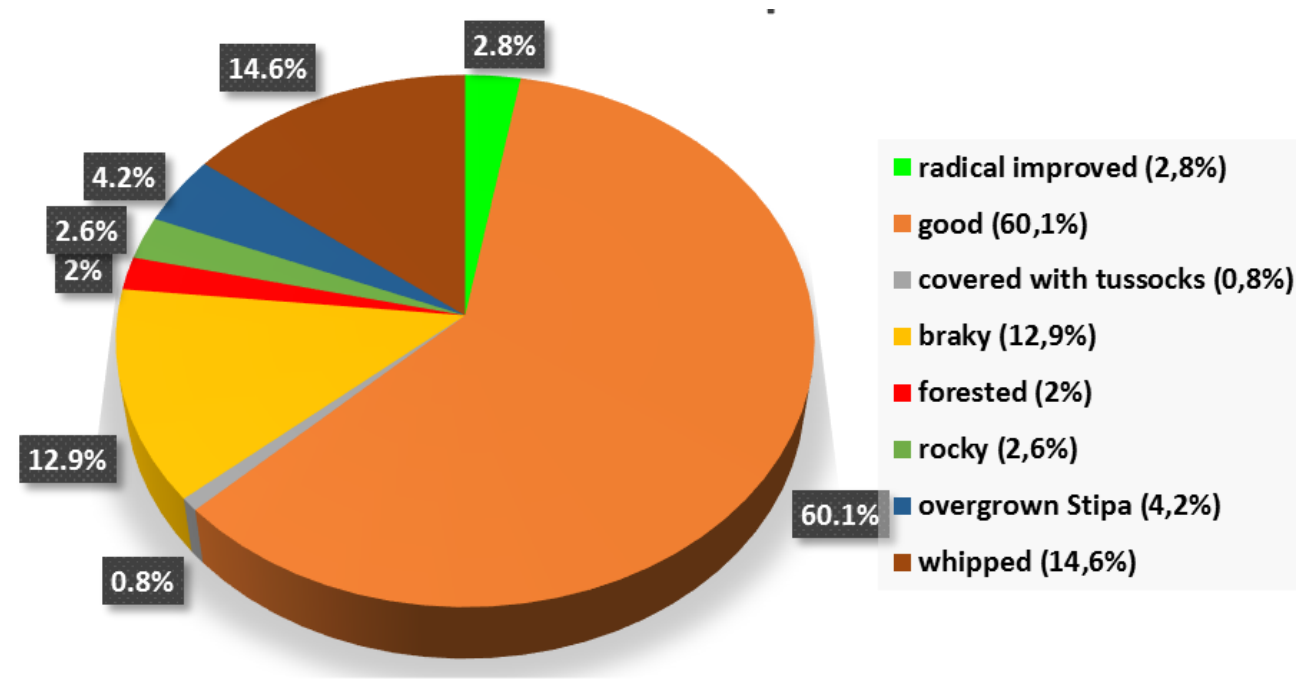

Figure 4. Current state of pastures

For the implementation, we set several goals: i) Explore the current state of soils irrigated areas piedmont plains Zhetysu Range: basic chemical, physicochemical and morphological properties of virgin and used in agricultural soils (30 incisions); ii) Develop criteria and parameters of soil degradation; iii) electronic versions of maps of soil degradation of the key area in scale of 1: 100,000.

Latest data on the state of land resources of the region belong to the 80s of the last century, and the intensive use of them led to a significant anthropogenic transformation. In the context of rainfed soil degradation manifested in the development of erosion processes, agro depletion of soils, reducing the productivity of agriculture. The use of land for irrigation often accompanied by secondary salinization. Unregulated grazing leads to rangeland degradation. In this regard, at present there is a need to assess the current state of the soil, with the identification of changes in their properties, because of the impact of various anthropogenic factors and the creation of new electronic soil maps and applications with modern technology.

\section{Material and Methods}

The study area is located in the zonal and related intrazo-functional soil piedmont plains of Kazakhstan of Zhetysusky ridge, $135 \mathrm{~km}$ to the east of the railway station Mulaly (line Semey-Almaty) and $155 \mathrm{~km}$ northeast of Taldykorgan (Figure 5). Its geographic lies between $078^{\circ} 11^{\prime} \mathrm{E}-079 \circ 55 \mathrm{E}$ longitude and $45^{\circ}{ }^{\prime} 16^{\prime} \mathrm{N}-45^{\circ}$ 24 ' N latitude. The altitude range of the study area is 1000-1500 m.a.s.l.

An integrated approach for evaluating current state of agricultural land and soil degradation foothill plains Zhetysu Ridge as adopted in this study, through the combined analysis of satellite imagery, supported by field work and previous work in the region.

The basic concept of defining the methods of obtaining the actual material and its processing is a genetic approach (Sokolov, 2004; Isachenko, 1980). The basis of investigation put the comparative geographical method (Korsunov et al., 2002).

Landsat ETM+ image and digital elevation model (DEM) were used in ENVI 4.7 software to produce the physiographic map of the studied area. Thirty soil profiles representing the different physiographic units were developed in the studied area. A detailed morphological description of soil profiles was carried out according to Rozanov (2004). The studied soil profiles were taken from comparative options as arable land and virgin soil to ensure the accuracy and validity of the field diagnostics of soils, soil mapping and morphological characteristics of the main properties of the soil.

The use of instrumental methods associated with laboratory analytical studies of samples, which carried by conventional methods (Arinushkina, 1962; Alexandrova et al., 1986). 


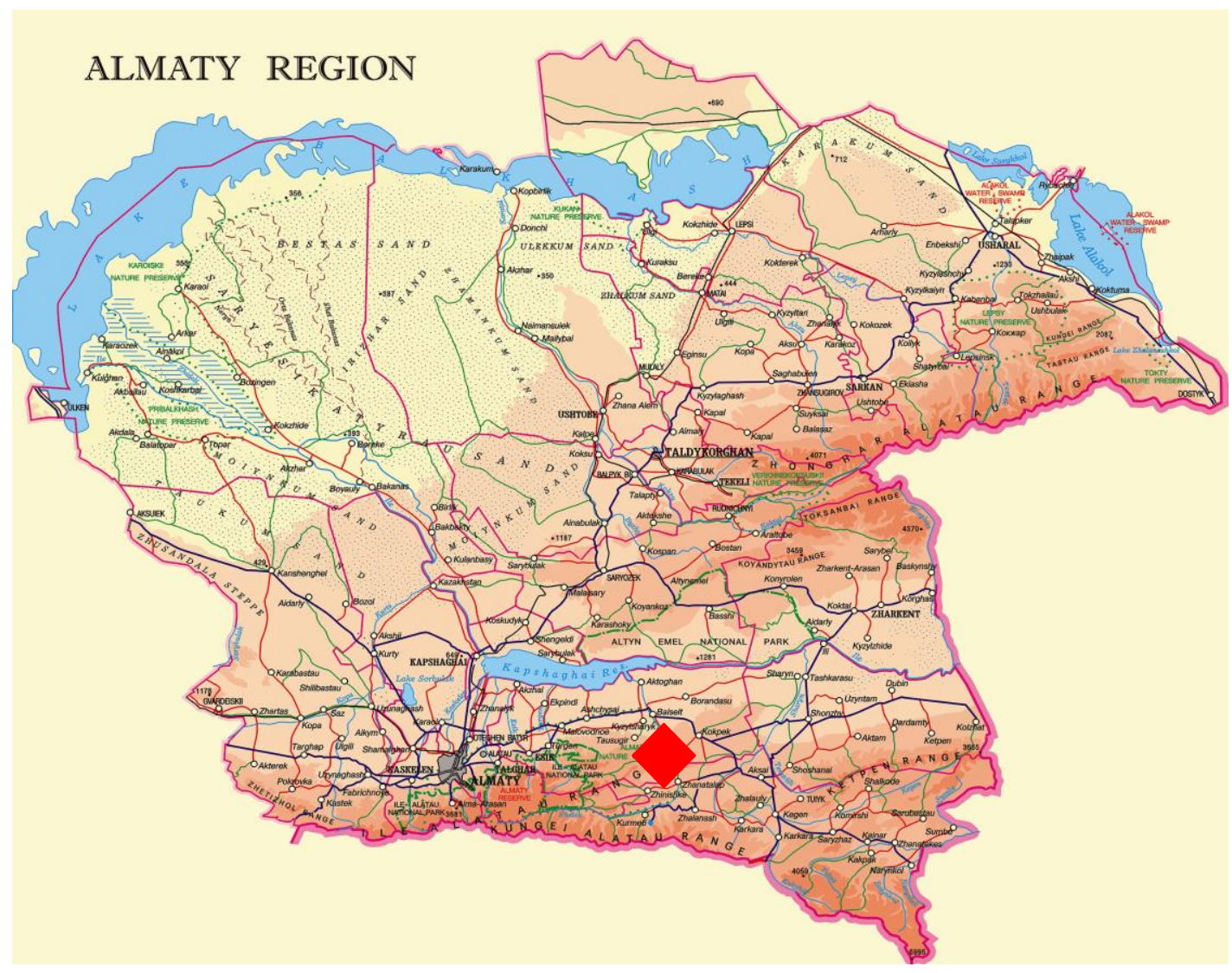

Figure 5. Location map of the study area

Preparation of a preliminary layout the test portion the soil map (1: 100 000) was carried out using conventional mapping techniques (Soil Survey, 1959), as well as with the use of GIS technologies and remote sensing data (Korsunov et al., 2002; Yashin et al., 2000). The basic method of processing space data is indirectly indicational decryption (Smirnov, 2005; Kravtsova, 2005), which is based on establishing a relationship with the soil components of the landscape, to get the best display on satellite images in the first place with vegetation and topography. In conducting research on the topic were used in deciphering largescale multispectral satellite images such as «Landsat», with the involvement of GoogleMap and BingMap. Work on the preparation of the soil map, was conducted in MapInfo Professional environment.

Preparation of the soil map was conducted as follows:

1. Pre-cameral work with space photographic materials - visual decryption, edge detection, saturation of their data as possible of past years of research.

As a result, pre-prepared the soil map layout. On that basis, outlines key areas, covering a total diversity of soil cover in representative locations for the development of methods of deciphering, and a detailed study in the field.

2. Field research conducted routing way to clarify the content of the selected contours, boundaries of soil zones, the establishment of deciphering features soil.

In the course of field works, preliminary cards are specified and supplemented.

\section{Extrapolation of final deciphering.}

For a reliable assessment of the degree of transformation of morphogenetic properties of soils characterized by the territory of the paired sections were laid (virgin land - arable land), occurring in the same conditions for terrain. The studies were conducted on dark brown, light-brown soils, ordinary gray soils of the northern, meadow-gray soils. 


\section{Results and Discussion}

In the process of work structure of soil database has been designed and prepared the tables in Microsoft Excel format for data entry. Collected, structured and entered into the database of soil data existing materials in their morphological, physical and chemical properties of zonal and intrazonal soils associated within the selected portion for 30 profiles. Used materials (Nikolaeva, 1969; Pachikin, 1991) obtained in the process of implementation of the program with the 1981-1985 years.

In 2015 was held 30 soil profiles for which morphological descriptions were made, selected and analyzed soil samples to determine their physical and chemical properties. The resulting material also incorporated in the soil database. The principal causes of soil degradation are few changes. Zaydelman brings them to the action of the five factors - hydrological, erosion, chemical, radiological, mechanical (Zaydelman, 2000). Karmanov and Bulgakov (1998) identified three main categories of soil degradation: physical or mechanical, biological, and biochemical and specific forms of their manifestation (erosion, dehumidification, condensation and formation of merge, increased acidity or alkalinity, alkalinity, secondary salinization and waterlogging) characterized as a kind of degradation (Karmanov and Bulgakov, 1998).

The main causes of soil degradation in all regions of Kazakhstan caused by three main factors: 1 . the extensive development of agricultural production; 2. resource-intensive development of the industry; 3 . the wide network of the former (in the Soviet period) military test sites (Kozybayeva, 2014). Because of these effects can develop various types and kinds of soil degradation. Type of soil degradation within the type characterized mainly by the deterioration of the specific properties of soils in the first stage (subsequently primary change of one will inevitably lead to transformation of all complex of properties of the soil). Alternatively, it is caused by distinctions in the factors of degradation causing identical reaction (for example, the different reasons cause remoistening, redrainage, etc.) or responses depend on a type of the same influence (for example, at pollution), etc. Table 1 (Gabbasova and Habirov, 2010).

Table 1. The typological taxonomy of soil degradation

\begin{tabular}{|c|c|c|}
\hline Type of degradation & Degradation Factors * & The types and forms of degradation \\
\hline Pollution & $\begin{array}{l}\text { 1 Exploration, production, transportation } \\
\text { and processing of minerals; } \\
\text { 2. Industrial, agricultural and household } \\
\text { emissions and waste; } \\
\text { 3.Technogenic catastrophes; } \\
\text { 4. Combustion of fuel. }\end{array}$ & $\begin{array}{l}\text { 1. Hydrocarbonic (oil crude and commodity, oil } \\
\text { products, oil slimes); } \\
\text { 2. Highly mineralized oil-field sewage; } \\
\text { 3. Heavy metals; } \\
\text { 4. Radiation; } \\
\text { 5. Biological; } \\
\text { 6.Gas-gene heathlands. }\end{array}$ \\
\hline Salinization & $\begin{array}{l}\text { 1. Drainage of solonchak marsh soils; } \\
\text { 2. Emergency floods of technogenic } \\
\text { brines; } \\
\text { 3. Violation of the mode of an irrigation. }\end{array}$ & $\begin{array}{l}\text { 1. Superficial; } \\
\text { 2. Deep-profile; } \\
\text { 3. Full-height; } \\
\text { 4. Sulphatic; } \\
\text { 5. Chloride; } \\
\text { 6. Soda. }\end{array}$ \\
\hline $\begin{array}{l}\text { Alkalinity and } \\
\text { solodization }\end{array}$ & $\begin{array}{l}\text { Developed under appropriate conditions } \\
\text { after technogenic salination instigated } \\
\text { sodium containing substances. }\end{array}$ & $\begin{array}{l}\text { 1. Continuous; } \\
\text { 2. Uneven; } \\
\text { 3. Focal. }\end{array}$ \\
\hline Pyrogenesis & $\begin{array}{l}\text { 1. The fires on the drained bogs; } \\
\text { 2. Wildfires; } \\
\text { 3. Combustion of straw and eddish. }\end{array}$ & $\begin{array}{l}\text { 1. With full loss of peat; } \\
\text { 2. With partial loss of peat; } \\
\text { 3. With the disturbed humus accumulative } \\
\text { horizon. }\end{array}$ \\
\hline landscape & $\begin{array}{l}\text { 1. Mining; } \\
\text { 2. Construction of dikes and dams; } \\
\text { 3. Karst (natural and technogenic). }\end{array}$ & $\begin{array}{l}\text { 1. Formation of embankments (waste heaps, } \\
\text { dumps, etc.); } \\
\text { 2. Formation of dredging (pits, ditches, trenches, } \\
\text { funnels, etc.). }\end{array}$ \\
\hline
\end{tabular}

\footnotetext{
* Degradation factor - the reason, the motive force of the process (phenomenon) degradation, defining its character or individual features.
} 


\section{Assessment of the current status of soil \\ Factors soil anthropogenic transformation}

Studies to evaluate the current state of soil of Zhetysusky ridge Sarkand area revealed that the ecosystem within the territory and characterized by soil cover in particular largely transformed under the influence of anthropogenic factors. The most intensive disturbances of natural soil and vegetation cover confined to foothill plains, where favorable climatic conditions and availability of sufficient water resources led to the intensive use of land in agricultural production. The types and extent of anthropogenic degradation of soil depend not only on the impact of a degradation factor, but largely determined by the genetic characteristics of the soils and lithology-geomorphological conditions of their occurrence.

When the soil irrigated agriculture, regardless of the typical belonging are undergoing a profound transformation, caused, in addition to mechanical and chemical effects associated with agro-technical measures for handling of arable land, a change in water regime with no washing on the washing. For irrigated lands as compared to virgin analogues characterized less differentiated by color and mechanical composition densified stretched profile with humus horizon. Loss of humus in the arable horizon can reach $50-60 \%$, especially in the first years of irrigation (Erokhina et al., 2004; Suleymenov, 2000). In the subsurface horizon, on the other hand, there is a relative increase in humus content.

With long-term irrigation of soils in the lower, (subsurface) of the profile occurs weighting texture, mainly due to the silt fraction. The texture of the arable horizon can vary significantly even within the same field due to the appearance of irrigation erosion, causing an increase in sand fraction washable area as well dusty and muddy - in accumulative. Changing the water regime leads to a shift deeper into the carbonate-illuvial horizon and washed out from the profile of water-soluble salts. Transformation of soil because of irrigation can have both negative and positive and depends on the duration of irrigation, irrigation water quality, the system used by agricultural activities and the type of land use. For example, soil gardens properties similar to virgin or analogs they observed significant improvement in the overall performance of fertility. With prolonged light gray soils irrigation with rational watering noted of humus enrichment, increasing absorption capacity, biological activity, improving micro aggregation. Significant areas of soils of foothill plains also used for rainfed agriculture. The annual distribution of rainfall with winter-spring maximum creates the opportunity for the successful cultivation are cereals, fodder and industrial crops.

Anthropogenic transformation of arable soil, in addition to purely mechanical disorders of the structure surface horizons and subsoil compaction horizon, related primarily to the decrease in humus content, caused by flushing and blowing humus composed of silt, humus mineralization and removal of nutrients with the harvest of crops. Accordingly, the physical properties deteriorate, exchange capacity decreases, micro- and macro elements content etc. (Rubinshteyn, 1985; Rubinshteyn and Tazabekov, 1988).

The development of rainfed agriculture in a steeply sloping- undulating piedmont plains leads to increased erosion. Noticeable symptoms of surface flushing not only observed at the surface slopes not exceeding 3-5 (Fedorin, 1977). Whereas the total area of arable rainfed foothill plains only $60 \%$ placed on the slopes with a slope and about $32 \%$ occupied by the slopes in 5-8 and over $8^{\circ}-$ more than $8 \%$ rainfed arable land. In the medium and strongly eroded soils almost half, the number of water-stable aggregates decreased by $20 \%$ reduces humus horizon. Surface horizons become layered-foliated addition and porous, and in the illuvial horizon B is a characteristic brown colour. Pasture degradation of soil takes place because of overloading the cattle lands. Overgrazing primarily manifested in violation of vegetative cover, sometimes until its destruction, accompanied by deterioration of physical, chemical and physico-chemical and biological properties of soils.

Under the conditions of weakly dissected topography piedmont plains of water erosion is almost not developed, but the sparseness of vegetation, high wind activity, insufficient soil moisture at immoderate grazing create preconditions for the development of deflation processes. It was found that even one-time run cattle destroys the surface layer of soil, and sprayed material is easily taken out even at a wind speed of 4-5 $\mathrm{m} / \mathrm{sec}$. Studies show that intensive grazing is causing losses of up to $30 \%$ of humus content, $20-50 \%$ of the elements of plant nutrition, and $10 \%$ of the absorption capacity. In addition, surface layers of an increase amount of water-soluble salts and carbonates (Muhametkarimov and Smailov, 2001).

Soil degradation because of anthropogenic impact is manifested in form of linear (road network communication lines, canals, pipelines, etc.) and local (residential-industrial zones, quarries, etc.) violations. 
It characterized as a rule, the complete destruction of the soil cover with the destruction of the original micro- and nano-relief and the formation positive technogenic topography (embankments, shafts) and negative (excavation, trench) forms. Which accompanied by a technogenic turbation (horizontal stratification loss, mixing substrates of different horizons) denudation (formation of soils with an incomplete or truncated profile) and buried soils extracted to the surface bedrock.

Residential and industrial land degradation associated with total destruction of the natural land cover and areas besides the placement of residential buildings and infrastructure captures the band width of 300-500 $\mathrm{m}$ around the settlements, which is a multi-faceted area of anthropogenic impact (transport, livestock, dirt and debris etc.) to form a fully converted from baseline soils of anthropogenic soils, mostly devoid of vegetation. Road digression of soil is an inevitable part of any kind of human impact. Lack of profiled surfaced roads, and they are often unsatisfactory condition leads to the formation of a dense network of dirt roads, which at year-round operation become impassable, and beside them a new form. As one of the main causes of the degradation of the physical properties of soils as a result traffic loads in favor of soil repacking, which is perhaps the most dangerous factor of vegetation degradation.

At consolidation of soils the cloddy low-porous structure is formed, the smallest moisture capacity, coefficient of a filtration and moisture pro-water content decreases (Ivanov, 1989). Even at insignificant biases of a surface leads to the accelerated development of processes of a water erosion. On light-textured soils, destruction of vegetation and disturbance of the structural condition of surface horizons leads to the formation of hearths deflation. Technogenic soil disturbance at their apparent locality can occupy large areas. It was found, that the laid asphalt and pipeline routes disturbed land area, excluding the indirect impact on the soil and vegetation cover reaches $2.3-2.5 \mathrm{~km}^{2}$ is $100 \mathrm{~km}$, to the existing dirt roads $-0.8 \mathrm{~km}^{2}$. The zone of indirect influence technological disturbances associated with the change of water and salt regime, the composition of the vegetation surrounding areas, captures an area of 2-3 times more (Asanbayev, 1998; Marynich, 1999).

\section{Determining the extent of degradation of soil test site}

For a reliable assessment of the degree of transformation of the territory characterized by the morphogenetic properties of soil were laid paired soil profiles in different versions (virgin - irrigated arable land, virgin land - arable land under rainfed), occurring in the same conditions. As you can see in Figure 6 sections and soil profiles, were carried out on dark brown, light-brown soils, ordinary gray soils of the northern and light, meadow gray soils.

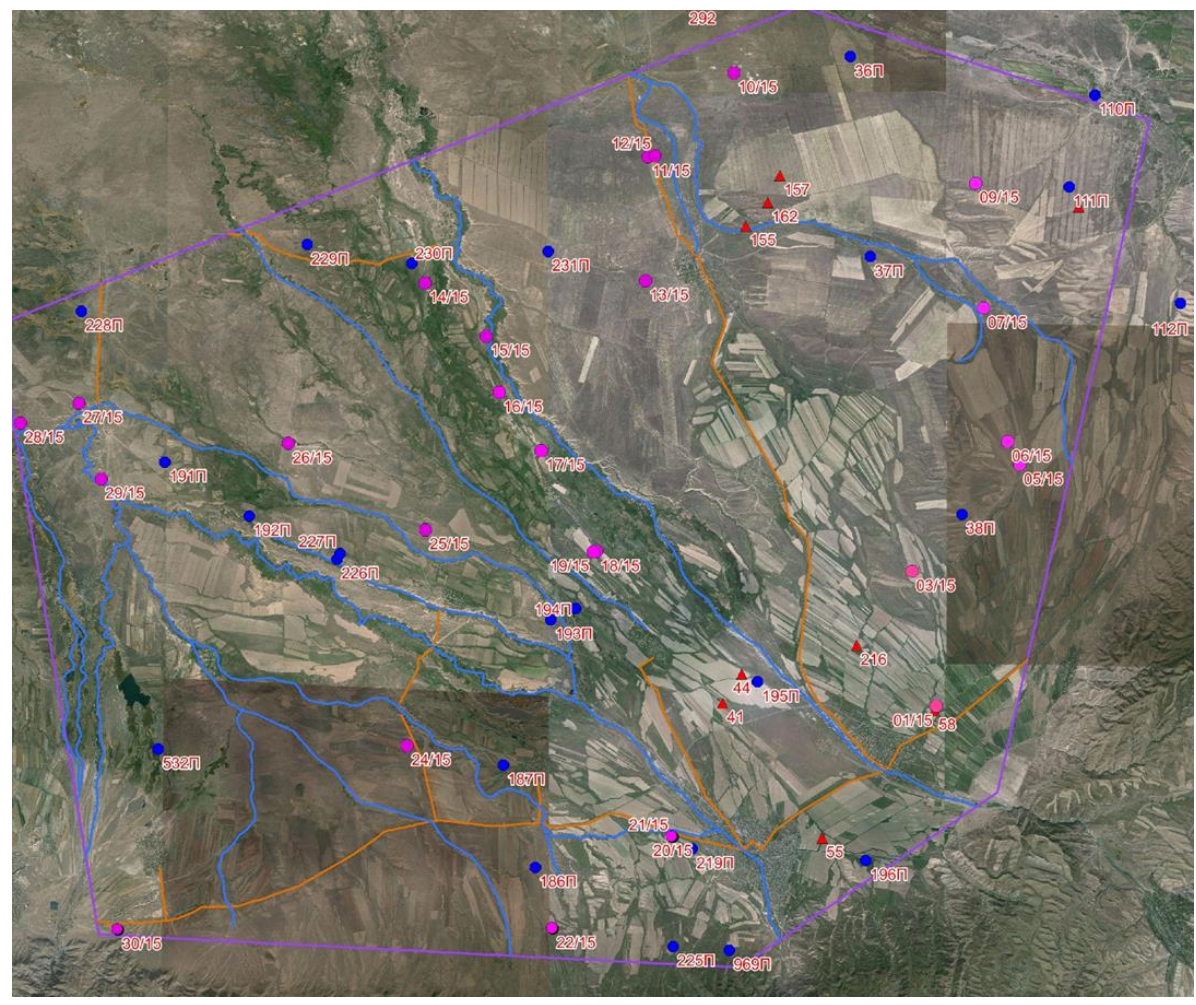

Figure 6. Scheme of arrangement of soil profiles on the test site 
The main morphological parameters that indicate the changes in the processes of soil formation are: the humus horizon $(A+B)$ and the depth of the upper boundary of the visually defined carbonates.

Changing these morphological parameters arable soils compared to virgin analogues shown in Figure 7.

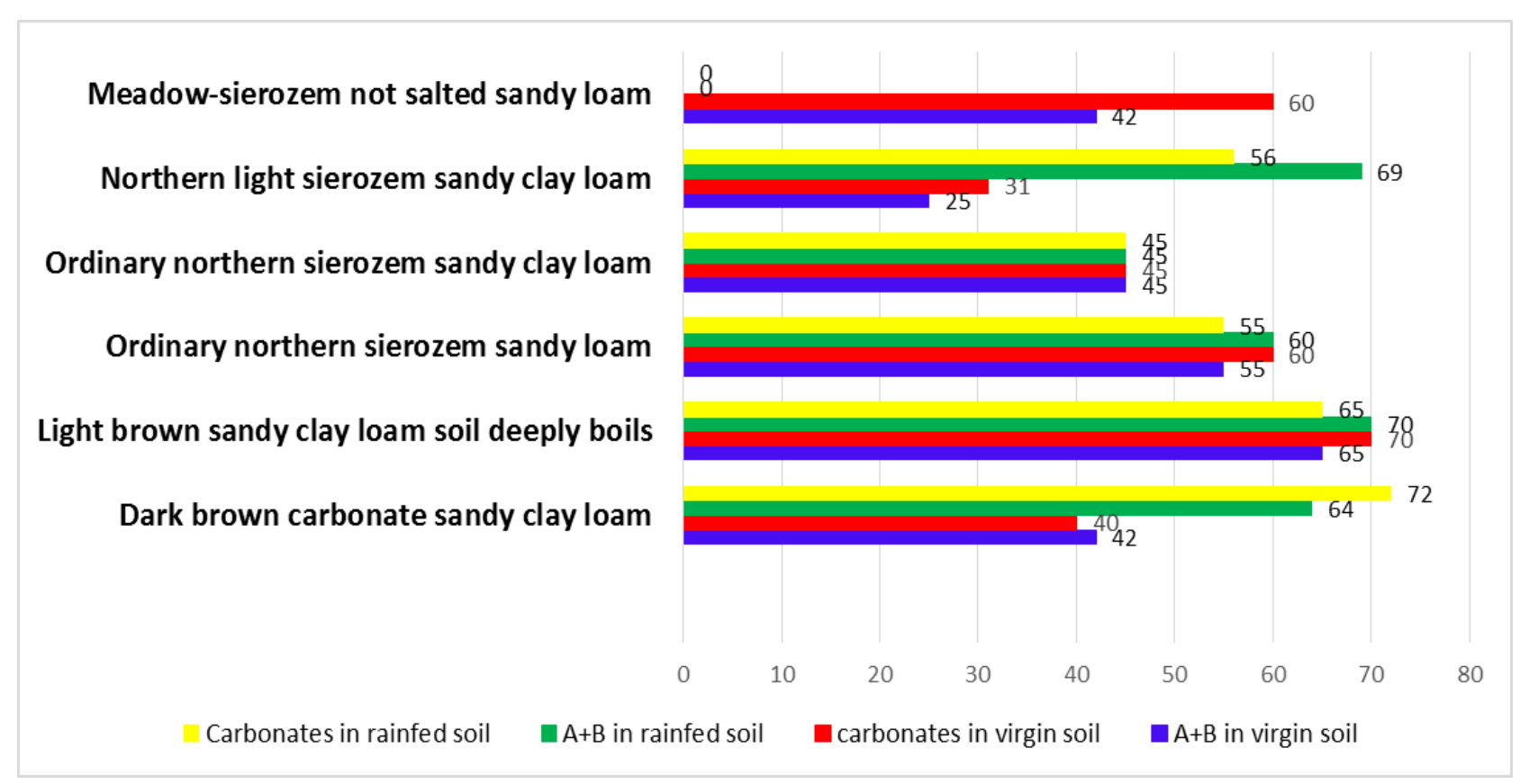

Figure 7. Changing the thickness of the humus horizon and depth of carbonates of arable soils in comparison with virgin counterparts.

As we see the boundary of on the profile of $A+B$, the deepest in the irrigated light brown sandy clay loam soil deeply boils, as virgin northern light sierozem sandy clay loam profile that is much poor.

According with the regulations of the Republic of Kazakhstan on protection of land resources (Environmental Requirements, 2005) and taking into account regional peculiarities of formation of soil study area identified the following criteria for determining the extent of arable land degradation, which you can see in Table 2.

Table 2. Criteria for determining extent of soil degradation

\begin{tabular}{|c|c|c|c|c|c|}
\hline Indicators & very weak & weak & medium & raised & high \\
\hline $\begin{array}{l}\text { Reducing the power of the soil profile }(\mathrm{A}+ \\
\mathrm{B}) \% \text { of original }\end{array}$ & $<3$ & $03-25$ & $26-50$ & $51-75$ & $>75$ \\
\hline $\begin{array}{l}\text { Reducing stocks of humus in the soil profile } \\
(A+B) \% \text { of original }\end{array}$ & $<10$ & $10-20$ & $21-40$ & $41-80$ & $>80$ \\
\hline $\begin{array}{l}\text { Reduction of clay on physical size,\% of the } \\
\text { original }\end{array}$ & $<5$ & $5-15$ & $16-25$ & $26-32$ & $>32$ \\
\hline $\begin{array}{l}\text { Area of bare parent rock (C) or bedrock } \\
\text { (B)\% of total area }\end{array}$ & $0-2$ & $3-5$ & $6-10$ & $11-25$ & $>25$ \\
\hline $\begin{array}{l}\text { Changing the } \mathrm{pH} \text { of soil environment, } \% \text { of } \\
\text { average }\end{array}$ & $<10$ & $10-15$ & $16-20$ & $21-25$ & $>25$ \\
\hline $\begin{array}{l}\text { The projected coverage of pasture } \\
\text { vegetation, } \% \text { of the zone. }\end{array}$ & $>90$ & $71-90$ & $51-70$ & $11-50$ & $<10$ \\
\hline \multicolumn{6}{|c|}{ The increase in exchangeable sodium content (in\% of the cation exchange capacity): } \\
\hline - soils containing $<1 \%$ sodium & $<1$ & $1-3$ & 3-7 & $7-10$ & $>10$ \\
\hline - for the other soil & $<5$ & $5-10$ & $10-15$ & $15-20$ & $>20$ \\
\hline
\end{tabular}

\section{Map of degradation of soils of a test site}

The degradation of the soil map of the test site, which is given in Figure 8, have been prepared on the basis of the soil map (Pachikin, 2016), the degree of soil degradation was determined by the results of the analytical examination of samples, taking into account the factors and criteria for soil degradation. 
Despite the advancement in the measurement of land degradation in Le et al. (2014), its definition as a longterm decline in the NDVI still entails some issues, since confounding factors changing over time, such as land use, influence the NDVI. Kazakhstan underwent a considerable transition in agricultural land use in the postSoviet era, marked by a sharp decline in total rainfed grain area from 25 million ha in 1983 to 14 million ha in 2003, particularly in the country's northern part (De Beurs and Henebry, 2004). Today, the area is largely covered by abandoned cropland returning to original land cover types prevalent before their conversion to cultivation (Schierhorn et al., 2013), mainly grassland. Although soil itself might have recovered some of its lost carbon due to abandonment (ibid.), cultivated land may elicit a higher NDVI value than abandoned land with sparser vegetation, leading to an overestimation of inherent soil degradation processes (Klein et al., 2012). Within the framework of solving the research tasks developed soil structure unified database based on scientifically sound methodology for assessing the current state of the soil. Cumulative to date soil information characterized by low availability, incompatible and often unreliable and incomplete. The study of natural resources, including soil, using modern computer technology has received in recent years widespread. However, for the Almaty region there is no single soil database tailored agro resource building land.

\section{DEGRADATION MAP OF SOIL COVER IRRIGATED AGRICULTURE TERRITORY OF PIEDMONT PLAINS ZHETYSU RIDGE}
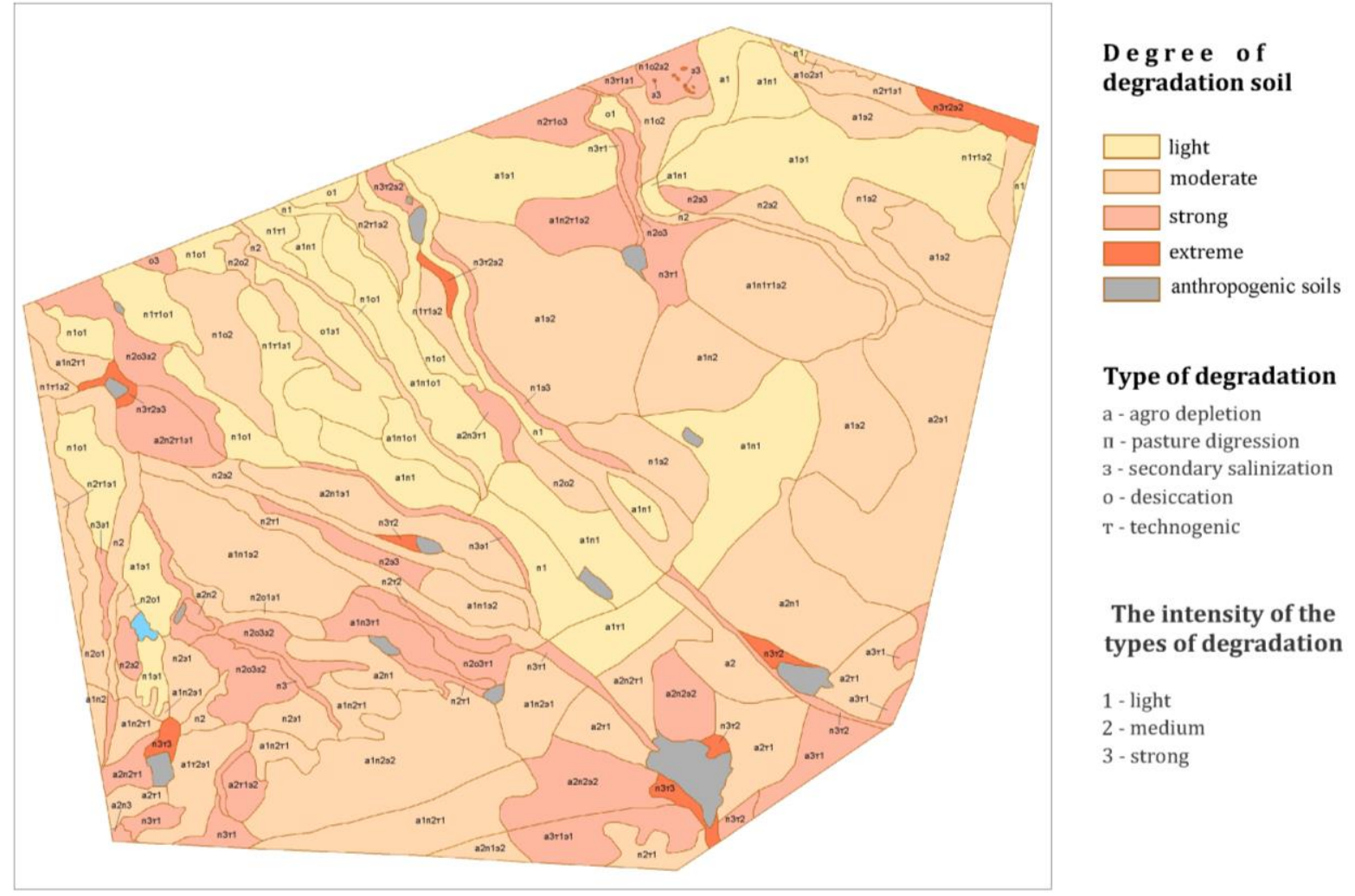

\section{Type of degradation}

a - agro depletion

$\mathrm{n}$ - pasture digression

3 - secondary salinization

o - desiccation

$\mathrm{T}$ - technogenic

The intensity of the types of degradation

1 - light

2 - medium

3 - strong

Figure 8. Map of degradation of soil test site

\section{Conclusion}

As a result, soil investigations Zhetysu ridge, obtained new data on soil properties and composed a largescale (1: 100 000) soil degradation maps using GIS technologies and remote sensing data. One of the most important tasks of development of Kazakhstan is to implement measures aimed at the preservation and reproduction of soil fertility because land degradation and desertification leads to a permanent reduction of the impact of material resources invested in agricultural production, undermining food and economic security of the Republic, worsens the living conditions of the population has a negative effect on health and demographic situation. The results of these studies are the basis for making decisions related to land use and environmental - of sustainable development of the territory schemes, regulatory and legal acts on the protection of soils, determining the measures to restore the natural landscape, the regulatory intensity of grazing pressure, the rational use of land. 
In accordance with the purpose of the study the following results were obtained: i) Based on existing materials and materials research 2015 (30 sections) designed and engineered soil data base on the territory of of the key area (150 ha.) Within the irrigated areas piedmont plain Zhetysusskogo ridge; ii) Developed parameters, types and criteria for soil degradation; iii) Compiled applied map of degradation soil of test site on a scale of $1: 100,000$.

\section{Acknowledgements}

The authors wish to thank Adamin Gabit, Songulov Ersultan, Ershibulov Azamat from KazSARI for their sampling of soil profiles.

\section{References}

Agency of Land Resources, 2011. Report on state land in Kazakhstan in 2011. Available at [Access date: 28.07.2016]: http://2011-2014.ecodoklad.kz/

Aleksandrova, L.N., Naydenova, O.A., 1986. Laboratorno-prakticheskie zanyatiya po pochvovedeniyu [Laboratory and practical classes of soil science]. - L.: Agropromizdat, - 295 pp. [in Russian]

Arinushkina, E.V., 1962. Rukovodstvo po himicheskomu analizu pochv [Guidelines for Chemical analysis of soil]. - M.: MGU, 491 pp. [in Russian]

Asanbayev, I.K., 1998. Antropogennyye izmeneniya pochv i ikh ekologicheskiye posledstviya [Anthropogenic changes in soils and their environmental consequences]. Almaty: ylym. 180 pp. [in Russian]

De Beurs, K.M., Henebry, G.M. 2004. Land surface phenology, climatic variation, and institutional change: analyzing agricultural land cover change in Kazakhstan. Remote Sensing of Environment 89(4): 497-509.

Dyusenbekov, Z., 1997. Problemyi zemelnyih otnosheniy i mehanizmyi perehoda k platnomu zemlepolzovaniyu [Issues of land relations and mechanisms of transition to the paid land use]. Mezhdunarodnyiy selskohozyaystvennyiy zhurnal [International Journal of Agriculture] (Vol. 6. pp. 11-14). Moscow. [in Russian]

Environmental requirements, 2005. Ekologicheskiye trebovaniya $\mathrm{v}$ oblasti okhrany $\mathrm{i}$ ispolzovaniya zemelnykh resursov ( $\mathrm{v}$ tom chisle zemel selskokhozyaystvennogo naznacheniya) [Environmental requirements in the field of land protection and use (including agricultural land)]. RND Okhrana zemelnykh resursov. MKh RK. Astana. 2005. [in Russian]

Erokhina, O.G., Nasyirov, R.M., Pachikin, K.M., Yakunin, G.N., 2004. Transformatsiya pochv podgornyih ravnin Zailiyskogo Alatau v rezultate orosheniya [Transformation of Soil piedmont plains Trans-Ili Alatau as a result of irrigation]. Aktualnyie problemyi pochvovedeniya [Actual Problems of Soil Science] (k 50-letiyu osvoeniya tselinnyih i zalezhnyih zemel). Almaty: Tetis, pp. 78-92. [in Russian]

Fedorin, Yu.V., 1977. Zemelnyie resursyi predgornyih ravnin Kazahstana [Land foothill plains of Kazakhstan]. - AlmaAta: Kaynar, 187 p. [in Russian]

Gabbasova, I.M., Habirov, I.K., 2010. Rasprostranenie, tipologiya i otsenka sostoyaniya degradirovannyih pochv respubliki Bashkortostan [The spread, typology and assessment of degraded soils of Bashkortostan] Vestnik BGAU/Vestnik BSAU, 22, 5-13. [in Russian]

Isachenko, A.G., 1980. Metodyi prikladnyih landshaftnyih issledovaniy [Methods Applied Landscape Research]. L.: Nauka, 222 p. [in Russian]

Ivanov, B.N., 1989. Vliyanie hodovoy sistemyi avtomobilya na fizicheskie svoystva pochv pod lesom [Effect of suspension system of the car on the physical properties of soils under forest]. Pochvovedenie [Soil science]. 7, 4754. [in Russian]

Karmanov, I.I., Bulgakov, D.S., 1998. Degradatsiya pochv: predlozheniya po sovershenstvovaniyu terminov i opredeleniy [Soil degradation: proposals on improvement of terms and definitions]. Kn.: Antropogennaya degradatsiya pochvennogo pokrova i meryi ee preduprezhdeniya [Anthropogenic degradation of the soil and its prevention measures]. (Vol. 1, pp. 5-7). Rosselhozakademiya, DOP pri RAN, Soil science institute after named V.V.Dokuchaev. M. [in Russian]

Klein, I., Gessner, U., Kuenzer, C., 2012. Regional land cover mapping and change detection in Central Asia using MODIS time-series. Applied Geography 35(1-2): 219-234.

Korsunov, V.M., Kraseha, E.N., Raldin, B.B., 2002. Metodologiya pochvennyih ekologo-geograficheskih issledovaniy i kartografii pochv [Methodology of soil ecological and geographical studies and soil mapping]. - Ulan-Ude: BNTs SO RAN, 2002.232 p. [in Russian]

Kozyibaeva, F.E., 2014. Pochvyi Kazahstana. Problemyi i puti ih resheniya [Soils of Kazakhstan. Problems and solutions]. Delovoy Kazahstan [Business Kazakhstan], 25(422). p. 5. [in Russian]

Kravtsova, V.I., 2005. Kosmicheskie metodyi issledovaniya pochv [Space methods of soil research]. M.: Aspekt-Press, 180 p. [in Russian]

Le, Q. B., Nkonya, E., Mirzabaev, A., 2014. Biomass Productivity-Based Mapping of Global Land Degradation Hotspots. ZEF-Discussion Papers on Development Policy No. 193. University of Bonn. 
Marynich, O.V., 1999. Transformatsiya stepnoy rastitelnosti pri dorozhnoy digressii [The transformation of steppe vegetation at the road digression]. Transformatsiya prirodnykh ekosistem i ikh komponentov pri opustynivanii [The transformation of natural ecosystems and their components with desertification]. Almaty: Naurzum. pp. 5561. [in Russian]

Medeu, A., Akiyanova, F., 2011. LADA Regional Training for Asian Countries 10-18th April 2011 in Beijing institute of geography land degradation status and desertification assessment in Kazakhstan Almaty, 2011 [in Russian]

Muhametkarimov, K.M., Smailov, K.Sh., 2001. Izmenenie fiziko-himicheskih svoystv pochvyi pri razlichnyih rezhimah vyipasa na estestvennom pastbische [Changing the physical and chemical properties of the soil at various modes of grazing on natural pasture]. Nauchnyie osnovyi vosproizvodstva plodorodiya, ohranyi i ratsionalnogo ispolzovaniya pochv Kazahstana [Scientific bases of reproduction of fertility, protection and rational use of soil in Kazakhstan]. Almaty: Tetis, pp. 228-231. [in Russian]

Nikolayeva, V., 1969. Pochvy Sarkandskogo raiona Taldy-Kurganskoi oblasti i ikh agroproizvodstvennaya gruppirovka: otchet o NIR (zaklyuchitelnyy) [Soils Sarkand area Taldykorgan area and agricultural industrial grouping: research report (final)]. «Institut pochvovedeniya»: ruk. Nikolayeva V. (Vol. 44, pp. 250). Alma-Ata. [in Russian]

Pachikin, K.M., Erokhina, O.G., Altynbekova, N.A., Omirzakova, A.N., Kusainova, M.D., Nasyrov, R.M.,Adamin, G.K., Lukbanova, R.S., 2016. Interim statement of the Programme 212: "Evaluation of the current state of agricultural land in South-East Kazakhstan (for example, foothills the plains ridge Zhetysu) Registration number: 0115 RK02030, Inventory number: 0215RK02371.66 p. [in Russian]

Pachikin, K.M., 1991. Pochvy i pochvennyi pokrov Severnogo Sklona Dzhungarskogo Alatau [Soils and soil cover of the North Slope of Jungar Alatau]: dis. kan. bio. nauk: 03.00.27/ Institut pochvovedeniya. - Alma-Ata. 264 p. [in Russian]

Rozanov, B.G., 2004. Morfologiya pochv [Soil Morphology]. - M.: Akademicheskiy proekt, 432 p. [in Russian]

Rubinshteyn, M.I., 1988. Bogarnyie pochvyi predgornyih ravnin Tyan-Shanya [Rainfed soil foothill plains of Tien Shan]. Alma-Ata: Nauka, 136 p. [in Russian]

Rubinshteyn, M.I., Tazabekov, T.T., 1985. Antropogennyie izmeneniya gumusa v pahotnyih pochvah Kazahstana [Anthropogenic changes of humus in arable soils of Kazakhstan]. Dostizheniya Dokuchaevskogo pochvovedeniya v Kazahstane [Achievements of the Dokuchaev Soil Science in Kazakhstan]. Alma-Ata: Nauka, pp. 33-43. [in Russian]

Schierhorn, F., Müller, D., Beringer, T., Prishchepov, A. V., Kuemmerle, T., Balmann, A., 2013. Post-Soviet cropland abandonment and carbon sequestration in European Russia, Ukraine, and Belarus. Global Biogeochemical Cycles 27(4): 1175-1185.

Smirnov, L.E., 2005. Aerokosmicheskie metodyi geograficheskih issledovaniy [Aerospace methods of geographical research]. - SPb.: Sankt-Peterburgskiy Universitet, 348 p. [in Russian]

Soil Survey, 1959. Pochvennaya s'emka [Soil survey]. M.: Izd-vo AN SSSR. 346 p. [in Russian]

Sokolov, I.A., 2004. Teoreticheskie problemyi geneticheskogo pochvovedeniya [Theoretical problems of genetic soil science]. - Novosibirsk: Gumanitarnyie tehnologii, 288 p. [in Russian]

Suleymenov, B.U., 2000. Povyishenie plodorodiya oroshaemyih serozemov Yuzhnogo Kazahstana [Increased fertility of irrigated sierozems South Kazakhstan]. Almaty: Sanat, 194 p. [in Russian]

Yashin, I.M., Shishov, L.L., Raskatov, V.A., 2000. Pochvenno-ekologicheskie issledovaniya v landshaftah [Soil and environmental studies in landscapes]. - M.: MSHA, 558 p. [in Russian]

Zaydelman, F.R., 1992. Estestvennoe i antropogennoe pereuvlazhnenie pochv [Natural and anthropogenic wetland soils]. SPb.: Gidrometizdat, 288 p. [in Russian] 